\title{
PENGARUH PENAMBAHAN ABU ARANG TEMPURUNG KELAPA TERHADAP KUAT GESER TANAH LEMPUNG DI DAERAH MAKARTI JAYA
}

\author{
Reffanda Kurniawan Rustam ${ }^{1 *}$, Herri Purwanto ${ }^{2}$, Adiguna $^{3}$, dan Indah Tiara Putri ${ }^{4}$ \\ ${ }^{1234}$ Prodi Teknik Sipil Fakultas Teknik Universitas PGRI Palembang \\ *Corresponding author, e-mail : reffandakurniawan@yahoo.com
}

\begin{abstract}
ABSTRAK
Bahan pengujian kuat geser yang digunakan pada penelitian ini adalah abu arang tempurung kelapa dengan variasi $0 \%, 5 \%, 10 \%$, dan 15\%. Pengambilan sampel tanah (tanah lempung) dengan metode handbor yang diambil pada kedalam 1-2 m. Adapun lokasi penelitian berada di Daerah Makarti Jaya Palembang. Pengujian pemadatan tanah standar (PTS) dilakukan di Laboratorium Mekanika Tanah Jurusan Teknik Sipil Universitas Sriwijaya dan pengujian direct shear dilakukan di Politeknik Sriwijaya Palembang. Hasil pengujian index properties menunjukkan bahwa tanah di Daerah Makarti Jaya memiliki berat jenis (Gs) tanah $1,81 \mathrm{~g} / \mathrm{cm}^{3}$ dan kadar air $(\omega) 116,615 \%$. Hasil dari pengujian PTS terhadap tanah asli didapatkan kadar air optimum $\left(W_{\text {opt }}\right)$ sebesar $18 \%$ dengan berat isi kering maksimum $\left(\gamma_{d \max }\right)$ sebesar 7,4 gr/ $\mathrm{cm}^{3}$. Berdasarkan hasil pengujian direct shear diperoleh nilai kohesi maksimum (c) terjadi pada campuran abu arang tempurung kelapa persentase 5\% yaitu 43,15 kPa. Nilai sudut geser maksimum dalam (ф) pada campuran abu arang tempurung kelapa $10 \%$ yaitu 18,23 . Nilai kuat geser maksimum ( $\tau$ ) terjadi pada campuran abu arang tempurung kelapa persentase $5 \%$ yaitu $43,8 \mathrm{kPa}$.
\end{abstract}

Kata kunci : Abu arang tempurung kelapa, tanah lempung, direct shear.

\section{PENDAHULUAN}

Transportasi air merupakan satu-satunya akses penghubung untuk berbagai kegiatan baik dari dalam ataupun luar wilayah di Desa Upang Kecamatan Makarti Jaya Kabupaten Banyuasin Provinsi Sumatera Selatan. Karakter tanah di daerah Makarti Jaya yaitu lempung maka sulit untuk mendapatkan tanah timbunan yang baik. Penambahan campuran zat aditif (abu arang tempurung kelapa) pada tanah setempat diharapkan dapat digunakan untuk timbunan oprit jembatan.

\section{TINJAUAN PUSTAKA}

\section{Tanah Lempung}

Tanah Lempung merupakan agregat partikel-partikel berukuran mikroskopik dan submikroskopik yang berasal dari pembusukan kimiawi unsur-unsur penyusun batuan dan bersifat plastis dalam selang kadar air sedang sampai luas. Dalam keadaan kering sangat keras, dan tak mudah terkelupas hanya dengan jari tangan. Permeabilitas lempung sangat rendah. lstilah "gumbo" digunakan, khususnya di Amerika bagian barat, untuk lempung yang keadaan plastisnya ditandai dengan wujudnya yang bersabun atau seperti terbuat dari lilin, serta amat keras. Pada kadar air yang lebih tinggi (basah) lempung tersebut bersifat lengket (Terzaghi,1967:5). Lempung (clays) sebagian besar terdiri dari partikel mikroskopis dan submikroskopis (tidak dapat dilihat dengan jelas bila hanya dengan mikroskopis biasa) yang berbentuk lempengan-lempengan pipih dan merupakan partikel- 
partikel dari mika, mineral-mineral lempung (clay minerals), dan mineral-mineral yang sangat halus lain (Das, 1995 :9)

\section{Arang Tempurung Kelapa}

Tempurung yang memiliki prosentase sebesar 12\% terhadap berat buah kelapa, merupakan hasil ikutan dari pengolahan buah kelapa (Grimwood, 1975) yang selama ini banyak dimanfaatkan sebagai bahan baku arang aktif dan bahan bakar pada perusahaan makanan. Menurut Djafar (1996) dalam Lay dan Novarianto (2006) komposisi tempurung kelapa terdiri dari 10,43\%, abu 8,94\%. lignin $27,39 \%$, selulosa $51,55 \%$ dan protein $0,85 \%$. Cara yang dapat dilakukan untuk mendapatkan arang tempurung kelapa, adalah dengan cara membakar tempurung tersebut arang tempurung dapat dijadikan pupuk organik karena mengandung unsur hara P, K dan unsur lainnya (Menon dan Pandalai, 1958).

Menurut Zulfa Hadiiyah (2014) pemanfatan kelapa selama ini belum optimal, hanya sebatas tempurung kelapa, dibakar bahkan dibuang begitu saja. Mengingat ketersediaannya yang cukup banyak, mudah di dapat dan nilai jualnya rendah mendorong untuk mengoptimalkan nilai tempurung kelapa tersebut. Selain itu, kandungan lignin, selulosa dan senyawa organik yang terkandung di dalam tempurung kelapa memberikan nilai kalor bakar yang cukup baik. Dengan demikian, tempurung kelapa sangat cocok untuk distabilisasi tanah lempung. Variasi campuran yang digunakan $0 \%, 5 \%$, dan 10\%, terhadap berat isi tanah.

Penelitian sebelumnya yang dilakukan oleh Karaseran (2015) dengan menggunakan arang tempurung sebagai bahan stabilisasi tanah lempung ekspansif, arang tempurung dapat memperbaiki sirkulasi air dan udara, sebagai media yang dapat mengikat karbon, dan dapat mengurangi swelling pada tanah karena mereduksi indeks plastis tanah. Hal tersebut yang menjadi latar belakang penggunaan arang tempurung sebagai bahan stabilisasi.

\section{Stabilisasi Tanah}

Stabilisasi tanah adalah suatu metode yang digunakan untuk meningkatkan kemampuan daya dukung suatu lapisan tanah, dengan cara memberikan perlakuan (treatment) khususnya terhadap lapisan tanah tersebut.

Dengan demikian dapat diketahui bahwa tujuan stabilisasi tanah adalah minimal untuk memenuhi satu dari empet sasaran berikut ini :

1. Untuk memperbaiki (meningkatkan) daya dukung tanah.

2. Untuk memperbaiki (memeperkecil) penurunan lapisan tanah.

3. Untuk memperbaiki (menurunkan) permeabilitas dan swelling potensial tanah.

4. Untuk menjaga ( mempertahankan ) potensi tanah yang ada (existing strength).

Berdasarkan mekanisme kerja komposit antara massa tanah dengan bahan stabilizer jenis stabilisasi tanah dapat dibedakan atas :

1. Stabilisasi kimia : yaitu stabilisasi dengan menggunakan bahan-bahan kimia memungkinkan terjadinya reaksi kimia, dan menghasilkan senyawa baru yang bersifat stabil dari pada senyawa yang terdapat dalam massa tanah sebelum stabilisasi dilakukan. 
2. Stabilisasi fisik : yaitu stabilisasi dengan menggunakan energi yang disalurkan ke lapisan tanah, sehingga memperbaiki karakteristik lapisan sesuai dengan tujuan dari stabilisasi yang diinginkan.

3. Stabilisasi mekanis : yaitu stabilisasi dengan menggunakan material sisipan ke lapisan tanah, sehingga mampu memperbaiki karakteristik massa tanah sesuai tujuan tindakan stabilisasi yang diinginkan. Stabilisasi mekanis sering juga disebut " perkuatan tanah (reinforcement earth)

4. Stabilisasi termal : yaitu stabilisasi dengan menggunakan panas (termal) untuk membakar material tanah, sehingga kadar air kristal massa tanah menjadi sangat rendah, yang memungkinkan ikatan senyawa dalam massa tanah lebih stabil (irreversible).

\section{Kuat Geser Langsung}

Kuat geser tanah adalah kemampuan tanah melawan tegangan yang terjadi pada saat terbebani. Keruntuhan geser (shear failure) tanah terjadi bukan disebabkan karena hancurnya butir-butir tanah tersebut tetapi karena adanya gerakan relatif antara butur-butir tanah tersebut. Kekuatan geser yang dimiliki oleh suatu tanah disebabkan oleh:

1. Pada tanah berbutir halus (kohesif) misalnya lempung kekuatan geser yang dimiliki tanah disebabkan karena adanya kohesi atau lekatan antara butir-butir tanah (c soil).

2. Pada tanah berbutir kasar (non kohesif) kekuatan geser disebabkan karena adanya gesekan antara butir-butir tanah sehingga sering disebut sudut gesek dalam ( $\varphi$ soil).

3. Pada tanah yang merupakan campuran antara tanah halus dan tanah kasar (c dan $\varphi$ soil). Kekuatan geser disebabkan karena adanya lekatan( karena kohesi) dan gesekan antara butir-butir tanah (karena $\varphi$ ). (Santoso, 1998: 45-47)

Kuat geser dinyatakan dalam rumus:

$$
\mathrm{S}=\mathrm{c}^{\prime}+\sigma^{\prime} \tan \varphi^{\prime}
$$

Dimana :

$$
\begin{aligned}
& S=\text { Kekuatan geser tanah } \\
& U=\text { Tekanan air pori } \\
& \sigma=\text { Tegangan total } \\
& \sigma^{\prime}=\text { Tegangan efektif } \\
& \varphi^{\prime}=\text { Sudut geser dalam efektif } \\
& c^{\prime}=\text { Kohesi }
\end{aligned}
$$

Hubungan antara tegangan total, tegangan efektif dan tekanan air pori diperlihatkan pada Gambar1 :

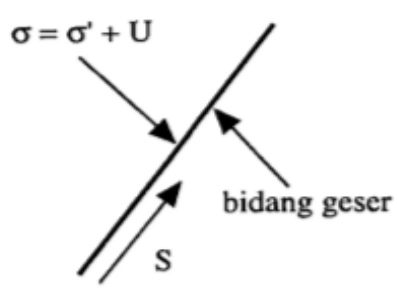

Gambar 1. Hubungan Antara Tegangan Total, Tegangan Efektif dan Tekanan Air Pori 


\section{Pengujian Kuat Geser}

Pengujian kuat geser dimaksudkan untuk mencari parameter-parameter dari tanah yang diperlukan dalam menentukan kuat geser. Percobaan untuk menentukan kuat geser dibagi menjadi (1) Drained test,(2) Undrained test, dan (3) Consolidated undrained test. Gambar 2 menjelaskan diagram pengujian geser langsung.

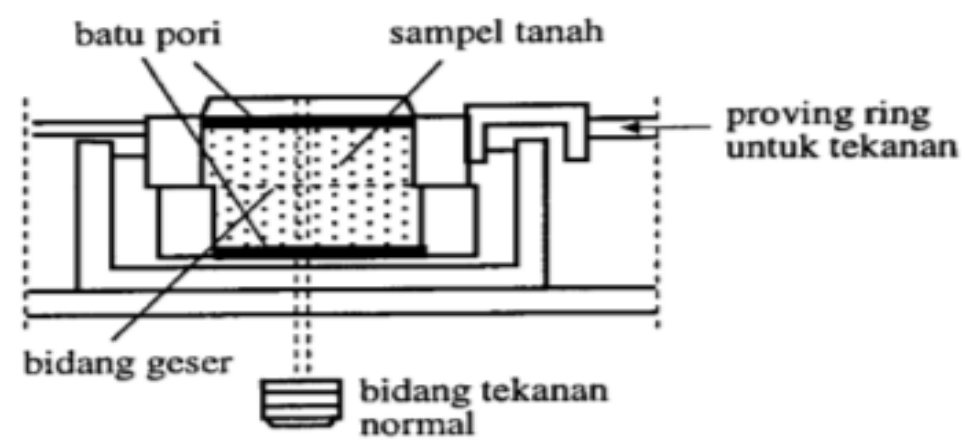

Gambar 2 Percobaan Geser Langsung

Sampel tanah berupa contoh tanah bertampang lingkarandan ditaruh didalam alat berupa dua buah cincin kemudian diatasnya diberi beban normal yang besarnya tetap. Sampel tanah digeser dengan gaya $\mathrm{T}$ yang besarnya berangsur-ansur dinaikan sampai tanah pecah digeser (TI) gaya TI pada saat tanah pecah dicatat.

$$
\begin{array}{c|c}
\text { Tegangan normal } & \sigma 1=\frac{N I}{A} \\
\text { Tegangan geser } & \mathrm{S}=\frac{T I}{A}
\end{array}
$$

\section{METODOLOGI PENELITIAN}

Metode penelitian yaitu pengujian laboratorium. Diagram alir penelitian dan lokasi penelitian ditunjukkan pada Gambar 3 dan Gamabr 4.

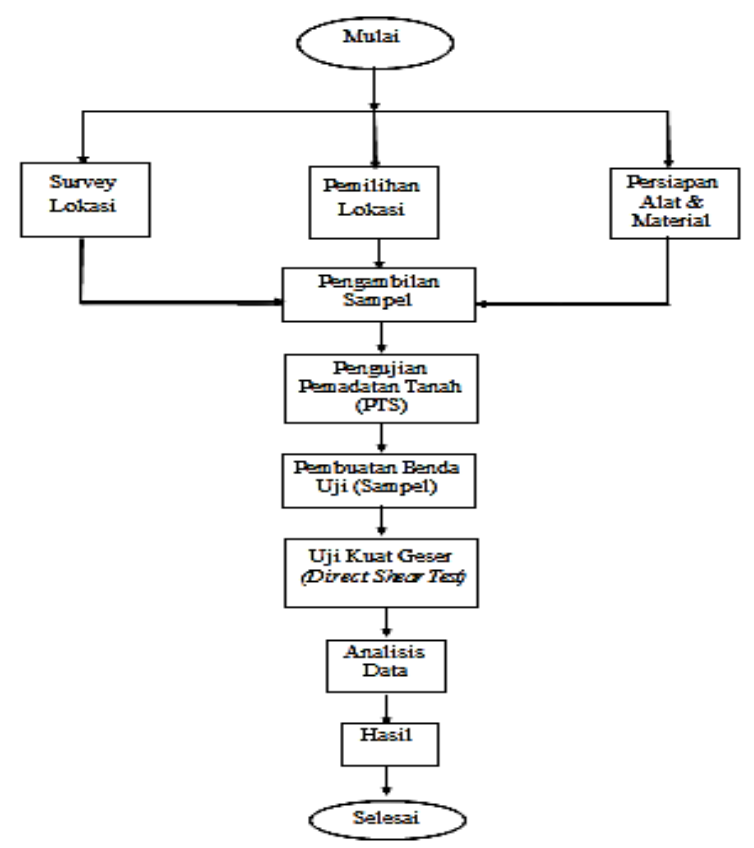

Gambar 3. Diagram Alir Penelitian 


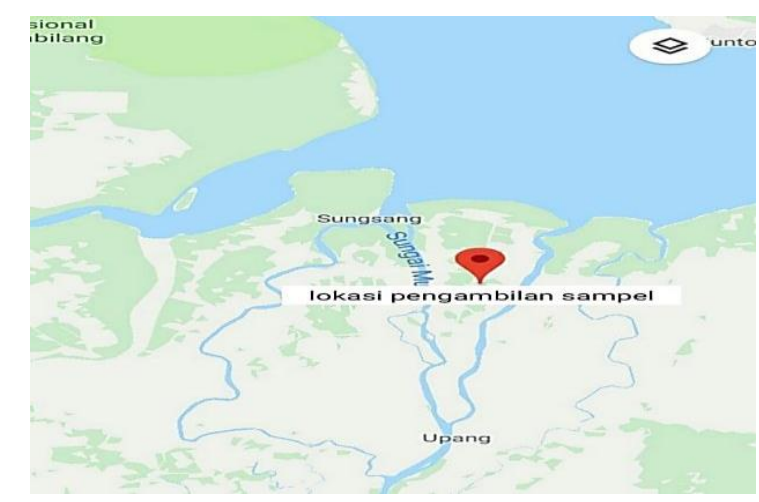

Gambar 4. Lokasi Pengambilan Sampel

\section{HASIL DAN PEMBAHASAN}

Hasil pengujian index properties diperlihatkan pada Tabel 1. Nilai kadar air tanah asli (w) sebesar 116,615\% dan Berat jenis tanah (Gs) sebesar $1,81 \mathrm{~g} / \mathrm{cm}^{3}$. Hasil pengujian tanah standar terhadap tanah asli didapatkan kadar air optimum $\left(\mathrm{W}_{\text {opt }}\right)$ sebesar $18 \%$ dengan berat isi kering maksimum $\left(\gamma_{\mathrm{d} \text { max }}\right) 7,4 \mathrm{~g} / \mathrm{cm}^{3}$ ditunjukka pada tabel dan gambar berikut :

Tabel1 1. Hasil pengujian index properties

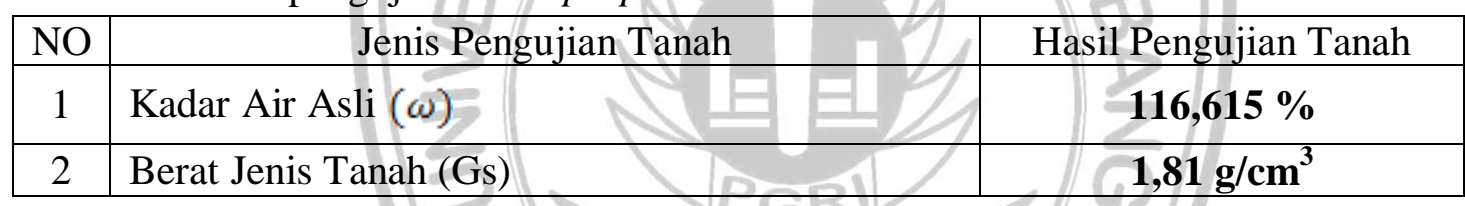

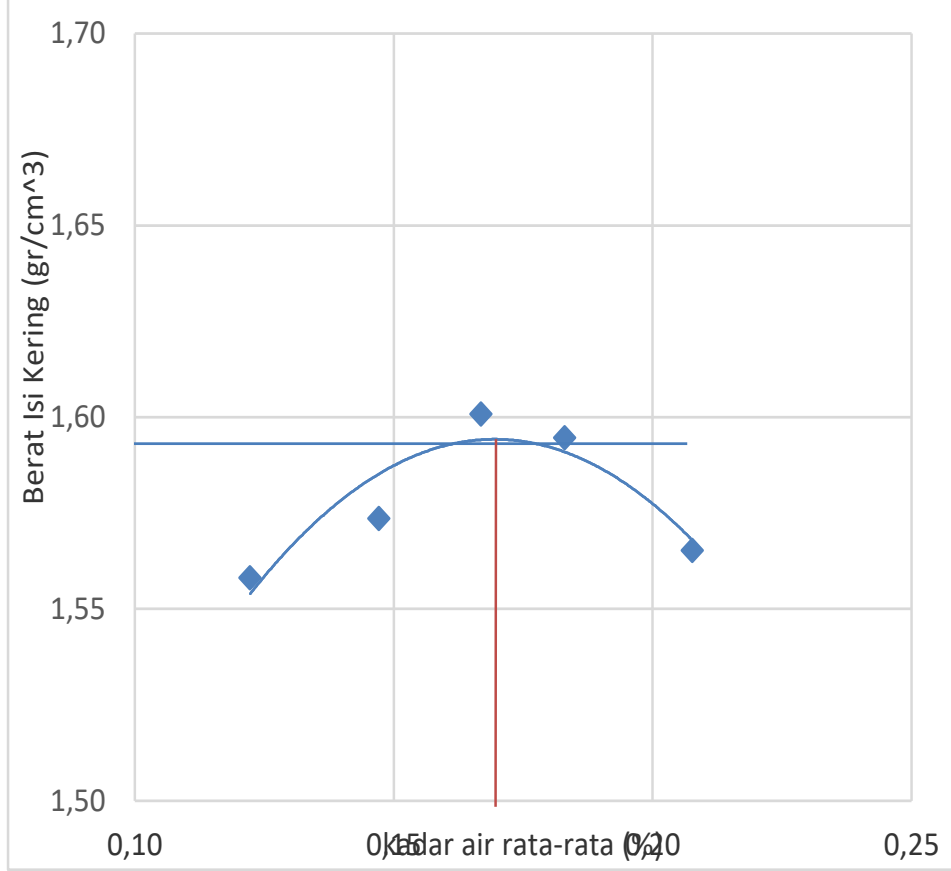

Gambar 5. Grafik Pemadatan Tanah Standar 
Pengujian direct shear bertujuan untuk mengetahui parameter kuat geser tanah yaitu nilai kohesi (C) dan sudut geser dalam $(\phi)$ pengujian direct shear. Penguiian ini menggunakan program Humboldt Testing Software. Sampel tanah J 48 idah ditambahkan dengan abu tempurung kelapa dengan variasi $0 \%, 5 \%, 10 \%$, dan $15 \%$, dilakukan 3 kali pengujian direct shear dengan 3 beban normal yang berbeda, jadi total pengujian direct shear pada penelitian ini sebanyak 12 kali dengan total sampel benda uji 12 sampel.

Beban yang ada sebesar $0,5 \mathrm{~kg}$, yang menghasilkan tegangan normal $49 \mathrm{kPa}$. Sehingga digunakan tegangan normal $49 \mathrm{kPa}, 98 \mathrm{kPa}$ dan $147 \mathrm{kPa}$ untuk melakukan pengujian direct shear. Hasil pengujian direct shear dengan program Humboldt Testing Software ditunjukkan pada Gambar 6, 7, 8, dan 9. Pada gambar 9., dapat diketahui nilai kohesi (c) sebesar 43,15kPa dan sudut geser dalam $(\phi)$ sebesar 8,15․ Tabel 2 dan Tabel 3 menjelaskan rekapitulasi hasil nilai kohesi tanah (c) dan sudut geser dalam $(\phi)$ dan rekapitulasi nilai kuat geser tanah.

Grafik nilai nohesi (c), grafik sudut geser dalam, dan grafik nilai kuat geser dijelaskan pada Gambar 10,11, dan 12.

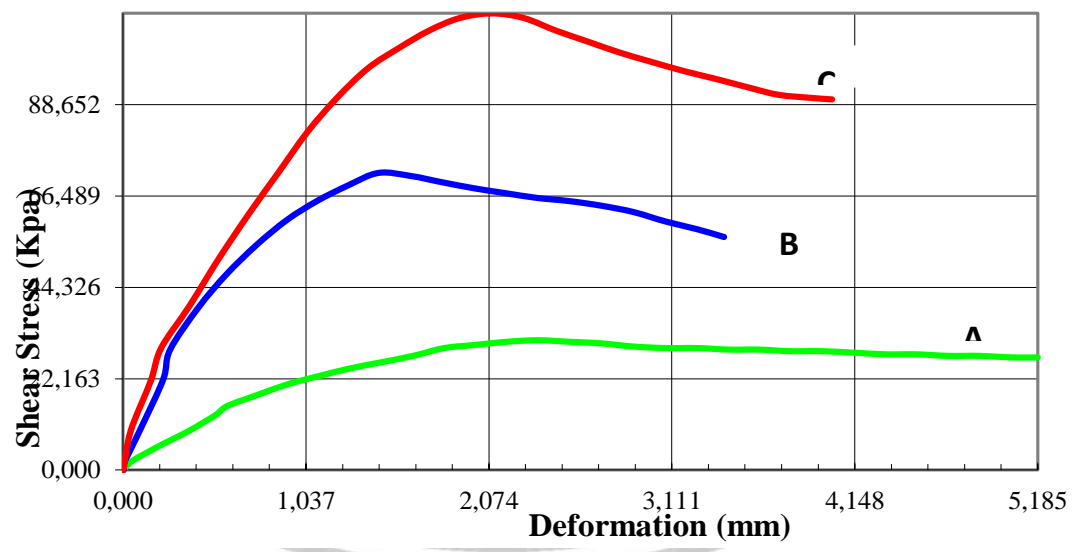

Gambar 6. Grafik hubungan antara pergeseran horizontal dan tegangan geser $0 \%$

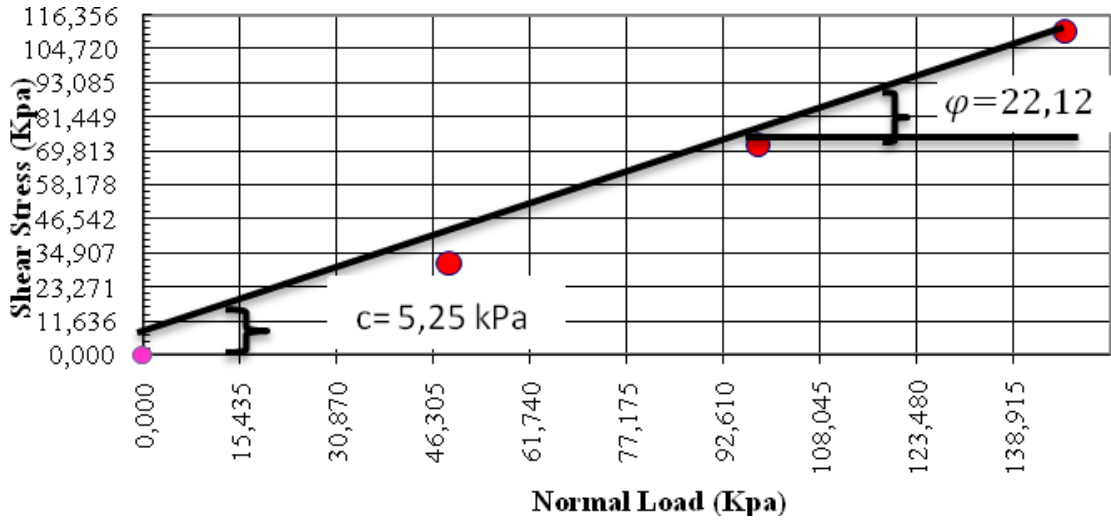

Gambar 7. Grafik hubungan antara tegangan normal dan tegangan geser maksimum $0 \%$ 


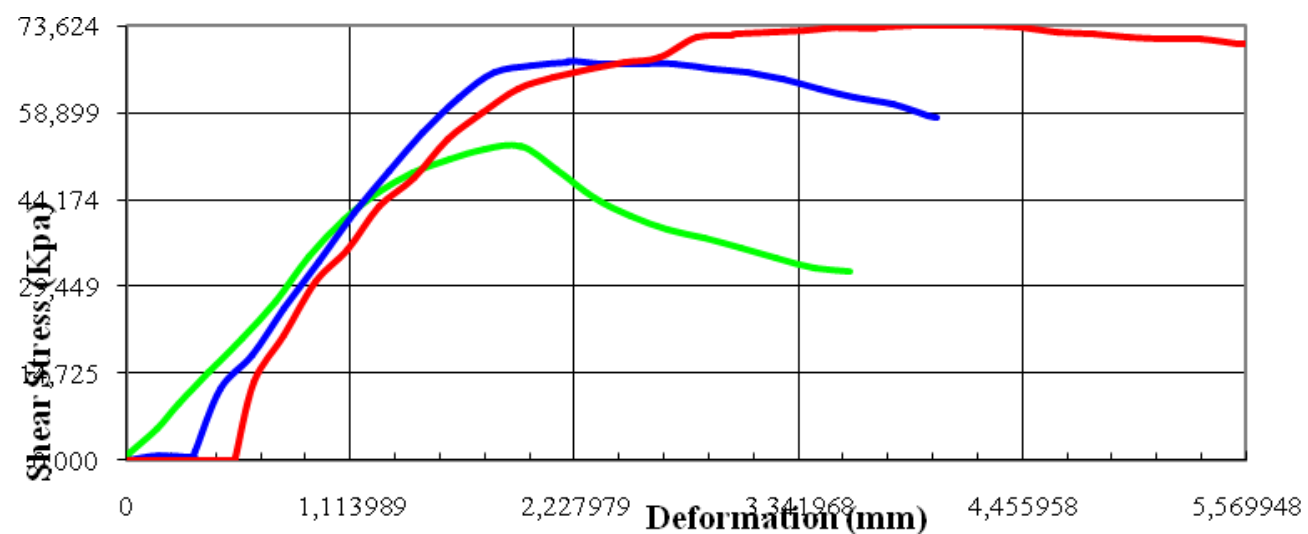

Gambar 8. Grafik hubungan antara pergeseran horizontal dan tegangan geser 5\%

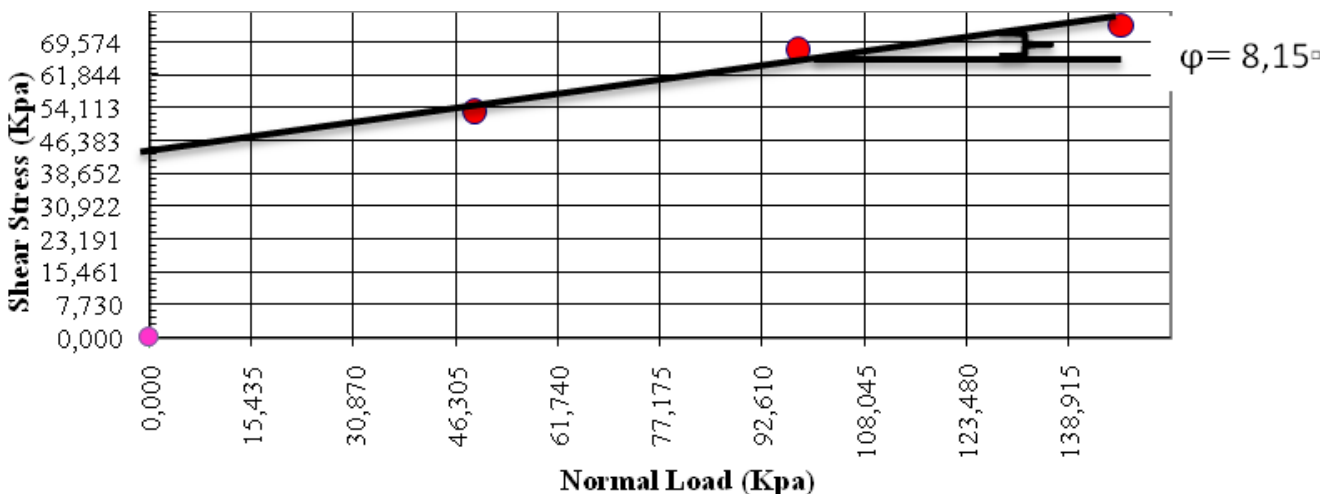

Gambar 9. Grafik hubungan antara tegangan normal dan tegangan geser maksimum 5\%

Tabel 2 Rekapitulasi hasil nilai kohesi tanah (c) dan sudut geser dalam $(\phi)$

\begin{tabular}{|c|c|c|}
\hline Kode & $\begin{array}{c}\text { Nilai Kohesi (c) } \\
(\mathbf{k P a})\end{array}$ & $\begin{array}{c}\text { Sudut Geser Dalam ( } \boldsymbol{\phi}) \\
(\mathbf{0})\end{array}$ \\
\hline Tanah Asli & 5,25 & 22,12 \\
\hline ATK 5\% & 43,15 & 8,35 \\
\hline ATK10\% & 3,23 & 18,23 \\
\hline ATK15\% & 22,15 & 18,9 \\
\hline
\end{tabular}

Tabel 3. Rekapitulasi Nilai Kuat Geser Tanah

\begin{tabular}{|c|c|}
\hline Kode & Nilai kuat geser $(\boldsymbol{\tau})$ \\
\hline Tanah asli & 6,564 \\
\hline ATK 5\% & 43,8 \\
\hline ATK $10 \%$ & 4,402 \\
\hline ATK 15\% & 23,351 \\
\hline
\end{tabular}




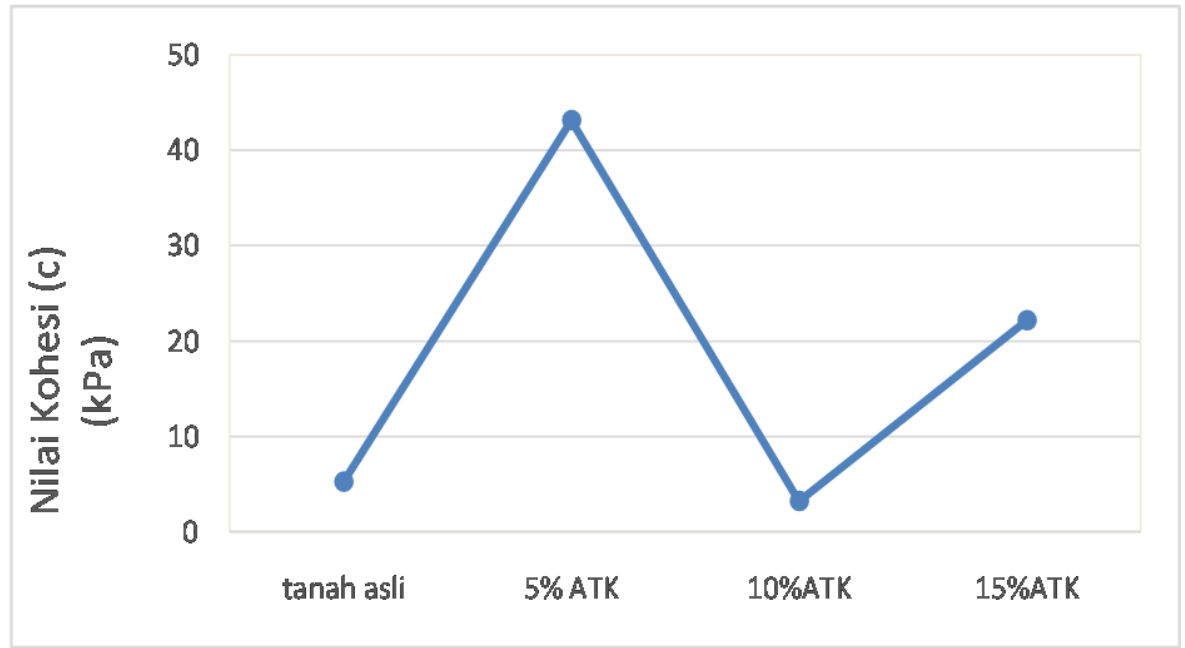

Gambar 10. Grafik Nilai Nohesi (c)

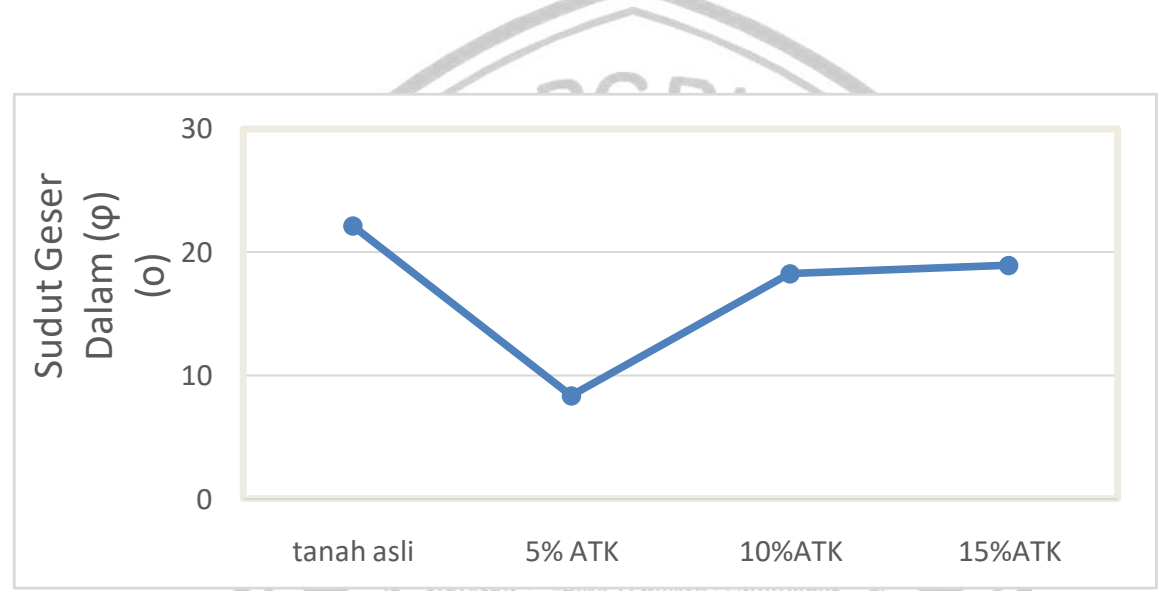

Gambar 11. Grafik Sudut Geser Dalam

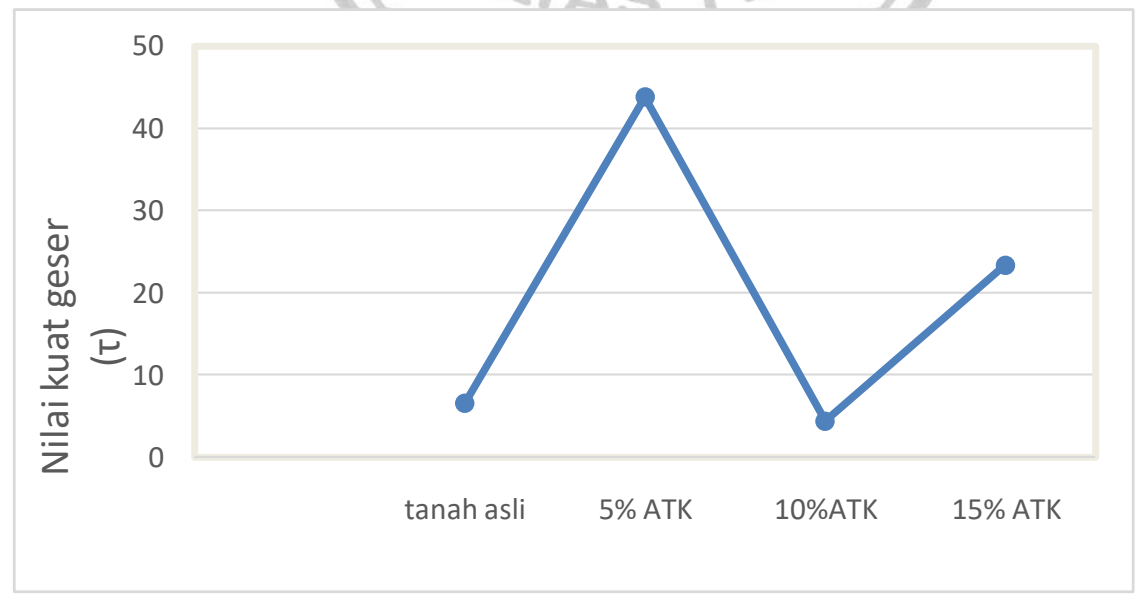

Gambar 11. Grafik Nilai Kuat Geser 
Hasil pengujian terhadap index properties tanah menunjukkan bahwa tanah memiliki kadar air asli $(\omega)$ sebesar $116,615 \%$, berat jenis tanah $\left(\mathrm{G}_{\mathrm{s}}\right)$ sebesar $1,81 \mathrm{~g} / \mathrm{cm}^{3}$, dengan kadar air optimum $\left(\omega_{\text {opt }}\right)$ sebesar $18 \%$. Rekapitulasi nilai rata-rata dari kohesi $(\mathrm{c})$, sudut geser dalam $(\phi)$ dan kuat geser $(\tau)$ sampel tanah dengan campuran abu tempurung kelapa dapat dilihat pada Tabel berikut. Rekapitulasi nilai rata-rata diperlihatkan pada Tabel 4.

Tabel 4. Rekapitulasi Nilai Rata-Rata

\begin{tabular}{|c|c|c|c|}
\hline Kode & $\begin{array}{c}\text { Kohesi } \\
(\mathbf{c}, \mathbf{k P a})\end{array}$ & $\begin{array}{c}\text { Sudut Geser Dalam } \\
\left(\boldsymbol{\phi}, \boldsymbol{}^{\circ}\right)\end{array}$ & $\begin{array}{c}\text { Kuat Geser Tanah } \\
(\boldsymbol{\tau}, \mathbf{k P a})\end{array}$ \\
\hline Tanah Asli & 5,25 & 22,12 & 6,564 \\
\hline ATK5 & 43,15 & 8,35 & 43,8 \\
\hline ATK10 & 3,23 & 18,23 & 43,8 \\
\hline ATK15 & 22,15 & 18,9 & 23,351 \\
\hline
\end{tabular}

Hasil pengujian direct shear, nilai kohesi (c) maksimum terjadi pada sampel tanah yang dicampur dengan abu tempurung kelapa sebanyak $5 \%$ yaitu 43,15 $\mathrm{kPa}$. Nilai sudut geser maksimum dalam (ф) terjadi pada sampel tanah yang dicampur dengan abu tempurung kelapa sebanyak $10 \%$ yaitu $18,23 \%$. Nilai kuat geser $(\tau)$ maksimum terjadi pada sampel tanah yang dicampur dengan abu tempurung kelapa sebanyak $5 \%$ yaitu $43,8 \mathrm{kPa}$.

Dari gambar 10, nilai kohesi (c) terlihat bahwa pada campuran abu tempurung kelapa 5\% mengalami kenaikan, dan pada campuran abu tempurung kelapa 10\% mengalami penurunan. Pada Gambar 11, terlihat bahwa nilai sudut geser dalam ( $\phi)$ campuran abu tempurung kelapa 5\% mengalami penurunan, itu terjadi karena tanah mengalami sedikit pergeseran yang disebabkan tanah memiliki nilai kohesi (c) yang tinggi karena partikel antar butir tanah terikat sangat kuat. Dan pada Gambar 12 terlihat bahwa campuran abu tempurung kelapa 5\% mengalami kenaikan, ini terjadi karena abu mengandung protein yang mengikat tanah bermateri organik terhadap lempung. Sebaliknya pada campuran abu tempurung kelapa $10 \%$ mengalami penurunan.

\section{KSEIMPULAN}

Berdasarkan hasil pengujian dan pembahasan dapat disimpulkan dalam penelitian ini, yaitu :

1. Kadar Air Asli (ڤ̉) sebesar $116,615 \%$ dan Berat Jenis Tanah (Gs) sebesar $1,81 \mathrm{~g} / \mathrm{cm}^{3}$, menunjukkan bahwa tanah daerah Upang Makarti Jaya memiliki kadar air yang tinggi dan berat jenis tanah yang rendah tanah seperti ini tidak cocok untuk jalan raya dan bangunan - bangunan tinggi.

2. Kadar air optimum $(W)$ berdasarkan hasil pengujian pemadatan tanah setandar (PTS) didapatkan kadar air optimum $(W)$ sebesar $18 \%$ dengan berat isi kering maksimum $(\gamma) 7,4 \mathrm{gr} / \mathrm{cm}^{3}$.

3. Hasil pengujian direct shear didapatkan hasil nilai kohesi (c), nilai sudut geser dalam $(\phi)$ dan nilai kuat geser $(\tau)$, yaitu:

a. Nilai kohesi (c) maksimum terjadi pada campuran abu tempurung kelapa persentase $5 \%$ yaitu $43,15 \mathrm{kPa}$. 
b. Nilai sudut geser maksimum dalam (ф) pada campuran abu tempurung kelapa persentase $10 \%$ yaitu $18,23^{\circ}$

c. Nilai kuat geser $(\tau)$ maksimum terjadi pada campuran abu tempurung kelapa persentase $5 \%$ yaitu $43,8 \mathrm{kPa}$.

4. Berdasarkan hasil pengujian terhadap tanah daerah Upang Makarti Jaya Kabupaten Banyuasin, dapat disimpulkan bahwa pada campuran 5\% abu tempurung kelapa dapat menaikkan kuat geser tanah.

\section{DAFTAR PUSTAKA}

Braja M Das, 1995. Mekanika Tanah ( Prinsip-Prinsip Rekayasa Geoteknis), Jakarta : Erlangga

Budi Gogot Setyo, 2011. Pengujian Tanah Dilaboratorium, Yogyakarta : Graha Ilmu

Craig R F, 1989. Mekanika Tanah, Jakarta: Erlangga

Mukti Aji. 2016. Tinjauan Kuat Geser Tanah Lempung Kecamatan Sukodono Kabupaten Sragen Yang Distabilisasi Dengan Bubuk Arang Kayu (Studi Kasus Tanah Lempung Sukodono, Sragen) [Skripsi]. Surakarta (ID): Universitas Muhamadiyah Surakarta.

Natalia sindy,dkk. 2018. Pengaruh Penambahan Abu Batu Bara Terhadap Kuat Geser Tanah Lempung. Jurnal Tekno. 16 (69).

Pangurinseng Darwis, 2001. Stabilisasi Tanah, Makassar : Universitas 45 Makassar Parapaga Reki Thomas,dkk. 2018. Pengaruh Penambahan Zeolite Terhadap Kuat Geser Pada Tanah Berlempung. Jurnal Sipil Statik. 6 (7) : 501-509

Reffanda K,dkk. 2017. Karakteristik Kuat Geser Tanah Merah. Simposium II UNIID. $12(1)$

Resti, Ayu 2018. stabilisasi tanah merah dengan menggunakan limbah gypsum [Skripsi]. Palembang (ID): Universitas PGRI Palembang

Santoso Budi dkk, 1998. Mekanika Tanah Lanjutan, Jakarta : Gunadarma

Soedarmo Djatmiko, 1993. Mekanika Tanah 1, Malang : Kaunisius

Terzaghi Karl, 1987. Mekanika Tanah Dalam Praktek Rekayasa, Jakarta : Erlangga

Yulianus R,dkk. 2006. Pemanfaatan Arang Tempurung dan Debu Sabut Kelapa sebagai Pupuk Organik. Buletin Palma. 31.

Zulfa H. 2014. Stabilisasi Tanah Lempung Dengan Campuran Arang Tempurung Kelapa Dengan Metode Direct Shear Test [ Skripsi]. Padang (ID): Universitas Andalas Padang. 